\title{
Personality traits and illness representations as predictors of life satisfaction in hypertensive adolescents and emerging adults
}

\author{
Urška Žugelj;, Luka Komidar and Maja Zupančič \\ Department of Psychology, Faculty of Arts, University of Ljubljana, Slovenia
}

\begin{abstract}
This exploratory study examined the role of illness representations and personality in hypertensive adolescents' and emerging adults' life satisfaction. Even though earlier research showed that illness representations and personality traits predict life satisfaction in paediatric samples suffering from other chronic illnesses, these associations were not yet explored on youth with essential hypertension. The 97 participants were assessed for demographic and medical data, life satisfaction, illness representations (own illness representations - OIR, and perceived important others' representations about participants' illness - PIOIR), and personality (self-report and peer-report). Regression analyses indicated that OIR and self-reported personality traits accounted for $24 \%$ of the variance in general life satisfaction, $33 \%$ of variance in family-related life satisfaction, $25 \%$ of variance in friendsrelated life satisfaction, and $25 \%$ of variance in self-related life satisfaction. When entering PIOR illness representations and peerassessed personality traits as predictors of life satisfaction domains, these predictors accounted for $29 \%$ of the variance in general life satisfaction, $23 \%$ of variance in family-related life satisfaction, $17 \%$ of variance in friends-related life satisfaction, $24 \%$ of the variance in the living environment-related life satisfaction, and $20 \%$ in self-related life satisfaction. More specifically, the personality traits of agreeableness (self-report), neuroticism (self-report) and openness (peer report), as well as the illness representations dimensions (OIR: concern and emotional burden; PIOIR: identity, comprehension, consequences and treatment control of PIOIR), were shown to be the most important predictors of different domains of life satisfaction.
\end{abstract}

Keywords: life satisfaction, personality traits, illness representations, essential hypertension, adolescents, emerging adults

\section{Osebnostne lastnosti in predstave o bolezni kot napovedniki zadovoljstva z življenjem pri adolescentih in mladih na prehodu v odraslost $z$ esencialno hipertenzijo}

\author{
Urška Žugelj;, Luka Komidar in Maja Zupančič \\ Oddelek za psihologijo, Filozofska fakulteta, Univerza v Ljubljani
}

\begin{abstract}
Povzetek: V raziskavi nas je zanimalo, v kolikšni meri lahko s predstavami o bolezni in osebnostnimi lastnostmi napovedujemo zadovoljstvo z življenjem pri mladih osebah z esencialno hipertenzijo. Čeprav rezultati predhodnih raziskav pogosto kažejo na pomembno napovedno vrednost obeh skupin prediktorjev na zadovoljstvo z življenjem v različnih pediatričnih populacijah z drugimi kroničnimi boleznimi, na področju esencialne hipertenzije ti odnosi še niso raziskani. V raziskavi je sodelovalo 97 mladostnikov in mladih na prehodu v odraslost, ki so izpolnili vprašalnike o demografskih in zdravstvenih značilnostih, zadovoljstvu z življenjem, predstavah o bolezni (lastne predstave in zaznave o predstavah o lastni bolezni pri pomembnih drugih) in osebnosti (samo-ocena in ocena s strani druge osebe). Z regresijskimi analizami smo odkrili, da lastne predstave o bolezni in samoocenjena osebnost pojasnijo $24 \%$ variance v splošnem zadovoljstvu z življenjem, 33 \% variance v zadovoljstvu z družinskim življenjem, $25 \%$ variance v zadovoljstvu na področju prijateljstva ter $25 \%$ variance na področju zadovoljstva samim s sabo. Ko smo v model vnesli zaznane predstave o bolezni pri pomembnih drugih ter oceno osebnosti s strani druge osebe, smo z modelom pojasnili $29 \%$ variance $\mathrm{v}$ splošnem zadovoljstvu z življenjem, 23 \% variance v zadovoljstvu na področju družine, 17 \% variance v zadovoljstvu na področju prijateljev, 24 \% variance v zadovoljstvu na področju življenjskega okolja ter 20 \% na področju zadovoljstva s samim sabo. Natančneje, osebnostne lastnosti sprejemljivost (samo-ocena), nevroticizem (samo-ocena) in odprtost (ocena drugega) ter dimenzije predstav o bolezni (skrb in čustvena obremenjenost pri lastnih predstavah ter identiteta, razumevanje, posledice in nadzor z zdravljenjem pri zaznanih predstavah pomembnih drugih) so bili najpomembnejši napovedniki posameznih področij zadovoljstva z življenjem.
\end{abstract}

Ključne besede: zadovoljstvo z življenjem, osebnostne lastnosti, predstave o bolezni, esencialna hipertenzija, mladostniki, prehod $\mathrm{v}$ odraslost

\footnotetext{
*Naslov/Address: dr. Urška Žugelj, Oddelek za psihologijo, Filozofska fakulteta, Univerza v Ljubljani, Aškerčeva 2, 1000 Ljubljana, e-mail: urska.zugelj@ff.uni-lj.si
}

Članek je licenciran pod pogoji Creative Commons Attribution 4.0 International licence (CC-BY licenca).

The article is licensed under a Creative Commons Attribution 4.0 International License (CC-BY license). 
Over the last decades, positive levels of life satisfaction have been associated with a broad range of positive personal, psychological, and social outcomes in youth. Furthermore, different aspects of life satisfaction have been recognized as important indicators of physical and mental health as opposed to a mere absence of illness or disability in adult and paediatric populations (Huebner et al., 2004; Marcionetti \& Rossier, 2016; Proctor, Linley, \& Maltby, 2009).

\section{Life satisfaction in adolescents and emerging adults with essential hypertension}

Our study focuses on life satisfaction in adolescents and emerging adults with essential or primary hypertension. Essential hypertension is a chronic condition characterized by elevated blood pressure with no identifiable physical origin and relatively non-symptomatic course of illness (Varda \& Gregorič, 2005). The illness can go unnoticed for years and the affected person can usually live a relatively normal life. However, untreated and thus uncontrolled chronically elevated blood pressure is recognized as one of the major risk factors for the development of several cardiovascular and renovascular diseases, i.e., congestive heart failure, myocardial infarction, renal disease, and stroke (Varda \& Gregorič, 2005). To avoid these adverse outcomes of high blood pressure, diagnosed patients are required to follow complex, lifelong treatment regimens consisting of controlled diet, exercise and other relevant life-style changes. In more severe cases medication is needed (Finset \& Gerin, 2008). Yet, since patients rarely perceive the symptoms and their everyday life is not significantly affected, they may find it hard or even unnecessary to follow medical recommendations. We must note however, that hypertension may not be nonsymptomatic for all patients and well-being may be reduced (Bardage \& Isacson, 2001; Hildingh, \& Baigi, 2010).

Considering the health benefits of higher levels of life satisfaction and at the same time the threat of severe complications and the necessity of everyday life modifications, monitoring relevant aspects of hypertensive patients' psychosocial adaptation to illness is essential. In our study, we focused on various domains of life satisfaction.

Life satisfaction is usually defined as a cognitive judgment of the degree of self-perceived positivity in one's overall life or in specific life domains (e.g., school, family, friends, self, community). It represents a component of subjective well-being, along with happiness, positive emotionality, and negative emotionality (with the latter two considered as an emotional component of well-being; Diener, Suh, Lucas, \& Smith, 1999). As such, life satisfaction measures are recognized to be relevant indicators of one's psychosocial functioning and/or adaptation to illness (Edwards, Patrick, \& Topolski, 2003; Huebner et al., 2004; Sawyer et al., 2005).

Although it is expected that illness itself considerably affects life satisfaction, several factors may moderate/mediate this association. For example, Diener et al. (1999) report that subjectively perceived health predicted life satisfaction: "If people can find a way to appraise their health positively, the adverse impact of illness or disability on life satisfaction can be mitigated" (pp. 17). Similarly, the extent to which adolescents defined themselves in terms of their illness was most problematic when they perceived the illness in highly negative terms (Helgeson \& Novak, 2007). Furthermore, self-rated health was found to be significantly related to many important outcomes in adolescents, such as school achievement, participation in sports and exercise, subjective well-being, family income, parent-child relationships, selfesteem, and quality of life, but unrelated to physical symptoms (Edwards et al., 2003).

\section{Illness representation dimensions and personality traits as predictors of life satisfaction}

According to Leventahl's Self-Regulation Model of Illness Representations (Leventhal Halm, Horowitz, Leventhal, \& Ozakinci, 2004; Petrie \& Weinman, 2012) we can expect illness representations to play an important role in the perceived life satisfaction of chronically ill persons. In Leventhal's model, individuals are active problem solvers who derive representations of illness. The model presents illness representations as a complex system organized along emotional and five cognitive themes (Broadbent Petrie, Main, \& Weinman, 2006; Petrie \& Weinman, 2006). The cognitive themes are identity (the symptoms associated with illness), perceived timeline of the condition (acute versus chronic illness beliefs), causal beliefs (personal ideas about the cause), perceived consequences, and cure/control beliefs (how personal actions and medical treatments can control the condition). Accordingly, perceiving illness to have more severe consequences, to last for longer periods of life (or even lifelong), as not amenable to personal or treatment control, incomprehensible, accompanied by many symptoms, emotionally demanding, and worrisome can all indicate stronger impact of illness on one's everyday life and functioning. Individuals rely on these representations to guide their responses to health threats. Through this impact on individual's coping strategies subjective well-being is also affected (Chong, Mackey, Broadbent, \& Stott, 2012).

Another feature of Leventhal's model is a multilevel perspective: illness representations are dependent on the multilevel context in which they emerge, with the characteristics of self at the first level, and the broader social and cultural contexts at higher levels. The levels interconnect via the feedback loop (Leventhal et al., 2004). This means that one's illness representations develop in a social context and are continuously being re-examined in communication with other people. Thus, it is sensible to examine the broader context and not only the patient's own illness representations. Salewski (2003) lists main reasons for assessing important others' representations: (i) important others can affect the patient's own illness representations; (ii) adequate support can facilitate development of more functional representations; and (iii) important others (their support) significantly predict coping with illness. Furthermore, a stronger cohesion in the understanding of illness among family members results in more effective coping with the illness and higher subjective well-being in adolescent patients (Salewski, 2003). In our study, we aimed to consider somewhat different aspect of 
illness representations. Besides asking our participants how they see their own illness, we also asked them to report on how they perceive their important others perceptions of this illness. In our opinion understanding one's perception of important others' construction of their illness can further refine our understanding of illness representations formation. Important others' understanding of own illness is salient only when it is perceived by the individual. We assume that one's coping with illness can be influenced by knowing that parents (or other relevant persons) are worried even when one is not being overly affected by her/his own disease.

The role of illness representations in different aspects of well-being was documented in patients with various chronic conditions for both adult and paediatric populations (see review in Hagger \& Orbell, 2003). For example, the following relationships in adolescents with diabetes were established (Edgar \& Skinner, 2003; Law, Kelly, Huey, \& Summmerbell, 2002): (i) perceptions of more severe consequences of illness were associated with lower levels of emotional well-being; (ii) perceptions of stronger illness identity were related to lower levels of emotional well-being; (iii) perceived higher treatment efficiency to control illness was connected to higher levels of overall well-being; and (iv) different coping mechanisms did not mediate the relation between illness representations and overall well-being. However, we did not find any reports in extant literature concerning these associations in adolescent and emerging adult hypertensive patients.

The next aspect of interest in our study were personality traits. Researchers thoroughly examined the role of personality traits in life satisfaction in adults, but to a lesser extent in youth (Proctor et al., 2009; Weber \& Huebner, 2015). In earlier studies, extraversion usually emerged as a main personality predictor of life satisfaction (or similar constructs, i.e., quality of life, subjective well-being). However, in later research emotional stability (or low level of neuroticism) was found to be a better predictor of life satisfaction than extraversion (e.g., Vitterso, 2001). A meta-analyses by Steel, Schmidt, and Shultz (2008; for earlier findings see DeNeve in Cooper, 1998) presented high correlations between Big-Five personality traits and all facets of well-being. More specifically, the study reported that more-extraverted, agreeable, conscientious, and emotionally stable individuals tend to experience higher levels of subjective well-being.

Fogle, Huebner, and Laughlin (2002) identified both extraversion and neuroticism as significant predictors of healthy adolescents' life satisfaction. The results indicated a direct negative effect of neuroticism on life satisfaction, whereas a positive relationship between extraversion and life satisfaction was mediated by the adolescents' social self-efficacy. One of a few studies assessing paediatric patients suggested that health-related quality of life has been successfully predicted by neuroticism, agreeableness, conscientiousness, and openness (e.g., De Bolle, De Clercq, De Fruyt, \& Benoit, 2008).

In the present study, we examined the predictive validity of illness representations and the Big Five personality traits for different domains of life satisfaction in hypertensive adolescents and emerging adults. Both illness representations and personality traits have been shown to affect life satisfaction in various populations. However, these relationships have not yet been studied in youth with hypertension. Due to scarce studies in these patients, we relied on previous research conducted with adolescents suffering from different chronic illnesses in establishing our hypotheses. First, we expected illness representations to predict life satisfaction significantly. Specifically, we proposed that the participants' perceptions of the stronger impact of illness on their everyday lives would predict lower levels of life satisfaction. We assumed this association to hold for the adolescents'/emerging adults' own representations and their perceptions of important others' representations. Second, in line with recent studies (Steel et al., 2008) we expected personality traits to predict life satisfaction across different domains. According to Weber and Huebner (2015) assessing specific life satisfaction domains in addition to global life satisfaction is important since one can exhibit different levels of satisfaction across these domains.

The findings obtained in our study could add to the growing body of literature addressing the factors underlying subjective well-being (specifically life satisfaction) in chronically ill adolescents and emerging adults. A better understanding of how personality relates to life satisfaction and how young patients perceive their high blood pressure may be important in enhancing education about long-term outcomes, tailoring specific recommendations for illness management and achieving treatment goals.

\section{Method}

\section{Participants}

We gathered data on 97 participants with essential hypertension, aged 13 to 23 years $(M=17.3$ years, $S D=2.3$ ) and undergoing outpatient treatment. Two-thirds $(66 \%)$ of the participants were males. Regarding education or employment status, $15 \%$ of the participants were enrolled in the $8^{\text {th }}$ or $9^{\text {th }}$ grade of a nine-grade elementary school, 55\% were secondary school students, $21 \%$ were university students, $3 \%$ were employed, and $6 \%$ were not enrolled in any form of education or employed at the time of data collection.

In addition to data on the existing diagnosis, we examined the duration of the diagnosis, the body mass index (BMI), and the recommendations for illness management in individual participants. With respect to diagnosis duration, most of the participants had had their diagnosis for one to four years $(M=27.9$ months, $S D=23.5)$. They had all received recommendations from their doctors to change their lifestyle in at least one way (i.e., low salt intake, low fat intake, regular exercise, or stress reduction). In addition, medication therapy was prescribed to $63 \%$ of the participants. A total of $29 \%$ of participants were recommended to follow all of the four lifestyle changes and were additionally prescribed medication.

\section{Instruments}

Demographics and medical data. Data on age, gender, educational status, and place of residence were obtained by a short questionnaire developed for the purpose of the study. Diagnosis duration and information on other potential 
coexisting conditions were obtained from patient charts. Data on body weight and body height were obtained from patient charts for those participants whose regular appointments were scheduled at the time of recruitment. In other cases, the participants provided relevant data for the assessment of their current state.

Illness representations. The 9-item Brief Illness Perception Questionnaire (BIPQ; Broadbent et al., 2006) was translated and adapted to Slovene to assess illness representations. For the purpose of the study, the term "illness" in the original questionnaire was replaced by "my high blood pressure". In BIPQ, single items are used to represent each of the 9 dimensions of illness perception: (1) consequences: perception of consequences in everyday life; (2) timeline: expectations about the duration of illness; (3) personal control: perception of the degree of personal control over illness; (4) treatment control: perception of the degree of control over illness due to received treatment; (5) identity: perceived symptoms of illness; (6) concern: concern over illness; (7) comprehension: understanding of illness; (8) emotional burden: experiencing emotional burden due to illness; and (9) cause: perceived cause of the illness. Dimesions concern and emotional burden represent the emotional aspect of illness representations whereas other dimensions represent cognitive aspects. Only the first eight items were used in our data analysis, because the item cause is a qualitative measure. The selected items were rated along a 10-point scale. Broadbent and colleagues (2006) reported good testretest reliability of the BIPQ over a three-week- (mean $r=$ .62; range from .48 to .70) and a six-week time interval (mean $r=.66$; range from .42 to .75 ), respectively. Our participants completed two versions of the questionnaire. In the first, they reported their own illness representations, and in the second they were asked to report how they perceive their important other's illness representations of their (i.e. participants') essential hypertension. We used the term "important other" in the questionnaire, thus allowing participants to choose the person they considered relevant. However, they were not required to specify the person they were referring to.

Personality. Personality was assessed using The Inventory of Child/Adolescent Individual Differences (ICID; Halverson et al., 2003; Slovene version: Zupančič \& Kavčič, 2009) in a self-report and peer-report format. Two versions of the questionnaire were included in the study, namely selfreport and peer-report version. While self-report version of the ICID was completed by our participants, they were also asked to provide a peer-report from an important other. The ICID is an age and culture neutral measure of child/adolescent personality traits. It features 108 items that are assessed along a 7-point rating scale ranging from 1 (much less than the average peer or not at all) to 7 (much more than the average peer). The items reflect common parental natural language descriptions of their children across seven countries. The ICID measures the Big Five personality traits: extraversion, neuroticism, conscientiousness, agreeableness (reversecoded), and openness. Sound psychometric properties have been demonstrated for the scales across ages, informants, and cultures (e.g., Halverson et al., 2003; Knyazev, Zupančič, \& Slobodskaya, 2008). The internal consistency measures obtained in our sample for the five personality traits were satisfactory, with $M \alpha$ of .86 for self-report (ranging from .76 to .91 ) and $M \alpha$ of .86 for peer-report (ranging from .83 to $.89)$.

Life satisfaction (LS). We employed the Multidimensional Students' Life Satisfaction Scale (MSLSS; Huebner, 1994; Žugelj, 2010). This self-report measure consists of 40 items rated on a 6-point Likert scale ranging from 1 (strongly disagree) to 6 (strongly agree). Five distinct domains of LS are assessed, i.e., family, friends, living environment, school, and self. The measure also allows calculation of a total life satisfaction score. The internal consistencies obtained in our sample for the specific LS scales were good, ranging from .78 to .91 . The internal consistency for the overall (general) life satisfaction was .87 . This is consistent with the previously documented good reliability and validity of MSLSS. Namely, the authors reported a coefficient alpha of .92 for the total score, while the internal consistencies of the specific domainscores ranged from .78 to .86 (Gilman, Huebner, \& Laughlin, 2000; Huebner, 1994).

\section{Recruitment and procedure}

A specialist doctor identified potential participants according to the following criteria: (1) diagnosis of essential hypertension, (2) diagnosis established at least four months prior to recruitment, and (3) no co-morbid chronic condition. The initial sample of 163 adolescents/emerging adults met all the imposed criteria. The potential participants were sent a written invitation to take part in the study or were approached personally during their regular visit at the clinic, whereas the participants whose regular visits were scheduled at the time of assessment provided reports at the clinic. Others who agreed to participate, but were not scheduled for regular visits at the time of data collection, were sent the assessment materials by mail. All of the participants received a battery of self-report questionnaires and were asked to return the completed forms to the first author of the study in person, or by mail in case of home assessment. To assess personality, the participants were also asked to obtain a peer assessment of their personality on an enclosed peer-report version of the personality questionnaire.

Out of the 163 potential participants, we were not able to contact 33, resulting in 130 contacted potential respondents. Of the 130 contacted respondents, 16 refused to participate (three of them claimed to have had no blood pressure-related problems at the time), and 16 initially agreed to participate, but did not return the questionnaires. Thus, 98 completed data sheets were received ( $75 \%$ return rate). Of these, one respondent was excluded due to missing data, so the final sample included 97 participants. With regard to age, the participants did not significantly differ from the nonparticipants $(\Delta M=$ 4.94 months, $t(159)=0.91, p=.36)$, and the gender structure was almost identical (34\% females among the participants and $33 \%$ females among the nonparticipants). We were not able to collect any other data on the nonparticipants.

The research was approved by The National Medical Ethics Committee of the Republic of Slovenia. Informed written consent was obtained for all participants (or by parents in case of underage adolescents). 


\section{Results}

Since our sample was diverse with regard to demographic and biomedical characteristics, we tested for any potential effects of these characteristics on the constructs under study (illness perception, personality, and life satisfaction [LS]). Controlling for age, the regression analyses suggested no systematic effects of age, gender, diagnosis duration, or BMI on illness representations, personality, or life satisfaction.

\section{Descriptive statistics for all studied variables}

Table 1 presents descriptive statistics for all variables under study. The scale-scores exhibit low to moderate levels of skewness and kurtosis. Regarding life satisfaction scores that were used as criterion variables in the subsequent regression analyses, the results show that the participants exhibited relatively high levels of general life satisfaction and life satisfaction across the specific domains, as all of the

Table 1. Descriptive statistics for all studied variables (illnes representations, life satisfaction, and personality)

\begin{tabular}{|c|c|c|c|c|c|}
\hline & $N$ & $M$ & $S D$ & skewness & kurtosis \\
\hline \multicolumn{6}{|c|}{ Illnes Representations (own; OIR) } \\
\hline Consequences & 97 & 3.36 & 2.62 & 0.42 & -0.86 \\
\hline Timeline & 97 & 5.52 & 2.91 & 0.06 & -0.77 \\
\hline Personal control & 97 & 5.34 & 2.75 & -0.33 & -0.65 \\
\hline Treatment control & 97 & 6.33 & 3.05 & -0.68 & -0.43 \\
\hline Identity & 97 & 2.46 & 2.38 & 1.02 & 0.63 \\
\hline Concern & 97 & 4.02 & 2.71 & 0.16 & -0.82 \\
\hline Comprehension & 97 & 6.32 & 2.73 & -0.45 & -0.52 \\
\hline Emotional burden & 97 & 3.81 & 3.09 & 0.40 & -0.98 \\
\hline \multicolumn{6}{|c|}{ Ilness representations (perceived in others; PIOIR) } \\
\hline Consequences & 97 & 4.09 & 2.87 & 0.18 & -1.12 \\
\hline Timeline & 94 & 5.77 & 2.94 & -0.10 & -0.87 \\
\hline Personal control & 95 & 5.64 & 2.74 & -0.21 & -0.83 \\
\hline Treatment control & 94 & 6.90 & 2.97 & -0.90 & -0.11 \\
\hline Identity & 96 & 2.91 & 2.54 & 0.76 & 0.06 \\
\hline Concern & 96 & 6.31 & 2.65 & -0.42 & -0.35 \\
\hline Comprehension & 96 & 6.75 & 2.57 & -0.49 & -0.21 \\
\hline Emotional burden & 97 & 4.35 & 2.97 & 0.11 & -0.94 \\
\hline \multicolumn{6}{|l|}{ Life Satisfaction } \\
\hline Family & 97 & 4.73 & 0.99 & -1.04 & 0.63 \\
\hline Friends & 97 & 5.50 & 0.52 & -1.17 & 0.90 \\
\hline School & 97 & 4.03 & 1.01 & -0.13 & -0.53 \\
\hline Living environment & 97 & 4.83 & 0.92 & -0.89 & 0.17 \\
\hline Self & 97 & 4.72 & 0.62 & -0.50 & -0.26 \\
\hline Total score & 97 & 4.78 & 0.52 & -0.19 & -0.03 \\
\hline \multicolumn{6}{|l|}{ Personality (self-report) } \\
\hline Extraversion & 97 & 5.03 & 0.72 & 0.51 & -0.31 \\
\hline Conscientiousness & 97 & 4.50 & 0.39 & 0.50 & 0.08 \\
\hline Agreeableness & 97 & 3.46 & 0.61 & 0.26 & -0.39 \\
\hline Openness & 97 & 5.08 & 0.71 & 0.55 & -0.29 \\
\hline Neuroticism & 97 & 3.28 & 0.78 & -0.42 & -0.23 \\
\hline \multicolumn{6}{|l|}{ Personality (peer-report) } \\
\hline Extraversion & 95 & 5.07 & 0.66 & 0.36 & 0.24 \\
\hline Conscientiousness & 95 & 4.52 & 0.44 & -0.07 & 0.18 \\
\hline Agreeableness & 95 & 3.39 & 0.68 & 0.32 & 0.54 \\
\hline Openness & 95 & 4.98 & 0.60 & 0.11 & -0.48 \\
\hline Neuroticism & 95 & 3.39 & 0.72 & 0.10 & 0.85 \\
\hline
\end{tabular}

Note: OIR = own illness representations. PIOIR = perceived important others` illness representation. 
mean values were above the mid-point of the 6-point scale. We also computed Pearson's correlation coefficients between all studied variables; due to the size of the correlation matrix, Table 2 is available as a supplemental material on the Horizons of Psychology web page. In general, the correlations between the scores follow the expected pattern. It is worth noting that the correlations between the OIR and PIOIR scores (of illness representations) are moderately high. Similarly, we can observe moderate (although slightly lower) correlations between the self- and peer-report personality scales-scores.

\section{Predicting general and domain-specific life satisfaction}

We conducted hierarchical multiple regression analyses to explore how the respondents' personality traits (self- and peer-rated) and illness representations (own representations - OIR and perceived representations of their important others - PIOIR) predict general and domain-specific LS.

Moderately high correlations between the OIR and PIOIR scores and between the self- and peer-report scores on the Big Five personality scales (see Table 2) could pose multicollinearity problems in the regression analyses. Therefore, when predicting a certain LS score, we carried out two separate regression analyses; in the first we entered the OIR scores and self-report personality scores as predictors, while the second analyses included PIOIR scores and peerreport scores as predictors. In all analyses we used the default Enter method, which means that all of the predictors in a certain analysis were entered simultaneously into the model. Due to a large number of regression analyses (and resulting large amount of results) Table 3 and 4 contain only the results for the statistically significant predictors in a certain model; the full results of the regression analyses are available as supplemental materials on the Horizons of Psychology web page.

Table 3 summarizes the (statistically significant) results of the regression analyses to evaluate the predictive power of self-reported illness perceptions and self-reported personality traits for general LS and its specific domains. Accordingly, $29 \%$ of the variance in general LS was accounted for by all self-report predictors. However, in this model agreeableness was the only statistically significant predictor. The participants who scored higher on agreeableness reported on higher levels of general LS.

Further, nearly one quarter of the variance $(23 \%)$ in family-related LS was explained. In this domain, concern (illness representations dimension) was the only significant predictor. The participants who express higher levels of concern about their illness appear to be more satisfied with their family life.

Friendship-related LS was significantly predicted by self-reported agreeableness, neuroticism, and illness representations dimension emotional burden. All included predictors accounted for $25 \%$ of variance. The participants who described themselves as more agreeable, emotionally stable, and emotionally burdened by their illness seem to be more satisfied with their friendships.

Agreeableness was the only significant predictor of schoolrelated life satisfaction. The participants scoring higher on agreeableness indicated higher levels of satisfaction in school domain compared to their less agreeable peers. In this LS domain $13 \%$ of variance was accounted for by all included predictors.

LS with one's living environment was significantly predicted by one predictor only, i.e., illness representations

Table 3. Summary of the hierarchical multiple regression for the Big Five personality traits (self-report) and eight own illness representation dimensions predicting general life satisfaction and domain-specific life satisfaction (the results for only the statistically significant predictors are presented; the full results are available here)

\begin{tabular}{|c|c|c|c|c|}
\hline Dependent variable / Predictor & $R^{2}$ & $B$ & $95 \%$ CI for $B$ & $\beta$ \\
\hline General life satisfaction & $.29^{* *}$ & & & \\
\hline Agreeableness $^{\mathrm{a}}$ & & -0.24 & {$[-0.42,-0.07]$} & $-0.29^{* *}$ \\
\hline Family-related life satisfaction & $.23^{*}$ & & & \\
\hline Concern & & 0.11 & {$[0.02,0.20]$} & $0.30^{*}$ \\
\hline Friendship-related life satisfaction & $.25^{*}$ & & & \\
\hline Agreeableness $^{\mathrm{a}}$ & & -0.29 & {$[-0.47,-0.11]$} & $-0.34^{* *}$ \\
\hline Emotional burden & & 0.04 & {$[-0.001,0.08]$} & $0.24^{\#}$ \\
\hline Neuroticism & & -0.16 & {$[-0.33,0.01]$} & $-0.24^{\#}$ \\
\hline School-related life satisfaction & .13 & & & \\
\hline Agreeableness $^{\mathrm{a}}$ & & -0.47 & {$[-0.85,-0.10]$} & $-0.29^{*}$ \\
\hline Life environment life satisfaction & .21 & & & \\
\hline Concern & & 0.08 & {$[-0.01,0.17]$} & $-0.23^{\#}$ \\
\hline Self-related life satisfaction & $.25^{*}$ & & & \\
\hline No predictors with $p<.10$ & & & & \\
\hline
\end{tabular}

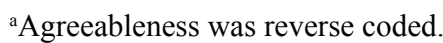

$N=97 ;{ }^{\#} p<.10,{ }^{*} p<.05,{ }^{* *} p<.01$. 
Table 4. Summary of the hierarchical multiple regression for the Big Five personality traits (peer-report) and eight illness representation dimensions (perceived in important others) predicting general life satisfaction and domain-specific life satisfaction (the results for only the statistically significant predictors are presented; the full results are available here)

\begin{tabular}{|c|c|c|c|c|}
\hline Dependent variable / Predictor & $R^{2}$ & $B$ & $95 \%$ CI for $B$ & $\beta$ \\
\hline General life satisfaction & .24 & & & \\
\hline Identity (PIOIR) & & -0.07 & {$[-0.12,-0.01]$} & $-0.32^{*}$ \\
\hline Comprehension (PIOIR) & & 0.05 & {$[-0.01,0.10]$} & $0.22^{\#}$ \\
\hline Family-related life satisfaction & $.33^{* *}$ & & & \\
\hline Comprehension (PIOIR) & & 0.11 & {$[0.02,0.21]$} & $0.28^{*}$ \\
\hline Identity (PIOIR) & & -0.11 & {$[-0.20,-0.02]$} & $-0.28^{*}$ \\
\hline Consequences (PIOIR) & & 0.08 & {$[-0.004,0.17]$} & $0.23^{\#}$ \\
\hline Friendship-related life satisfaction & .17 & & & \\
\hline Identity (PIOIR) & & -0.06 & {$[-0.12,-0.01]$} & $-0.31^{*}$ \\
\hline School-related life satisfaction & .17 & & & \\
\hline \multicolumn{5}{|l|}{ No predictors with $p<.10$} \\
\hline Life environment life satisfaction & .24 & & & \\
\hline Identity (PIOIR) & & -0.11 & {$[-0.20,-0.03]$} & $-0.32^{*}$ \\
\hline Openess (peer-report) & & -0.38 & {$[-0.76,-0.01]$} & $-0.26^{*}$ \\
\hline Self-related life satisfaction & .20 & & & \\
\hline Treatment control (PIOIR) & & 0.05 & {$[0.001,0.10]$} & $0.25^{*}$ \\
\hline Comprehension (PIOIR) & & 0.06 & {$[-0.01,0.12]$} & $0.22^{\#}$ \\
\hline
\end{tabular}

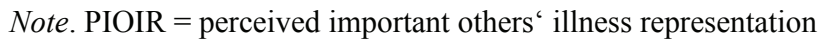

${ }^{\mathrm{a}}$ Agreeableness was reverse coded.

$N=97 ;{ }^{\#} p<.10,{ }^{*} p<.05,{ }^{* *} p<.01$.

dimension concern. All of the predictors accounted for $21 \%$ of variance in this LS domain. The participants experiencing lower levels of concern about their illness tended to report on higher levels of satisfaction with their living environment than their more concerned peers.

Although the included predictors accounted for $25 \%$ of variance in the self-related LS, none of the predictors turned out to be statistically significant.

Table 4 summarizes the results of the regression analyses to evaluate the predictive power of the participants' perceptions of important others' illness representations and peer-reported personality traits for general LS and its specific domains.

All included predictors accounted for $24 \%$ of variance in general LS. Among them identity and comprehension dimensions of the participants' perceptions of important others' illness representations were statistically significant. In participants who perceived their important others to acknowledge low illness identity and higher levels of understanding the illness general LS tends to be higher.

Further, three dimensions of perceived important other's representations of the participants' illness emerged as significant predictors of family-related LS. Namely, higher scores on comprehension and consequence scales and lower scores on the identity scale were associated with higher levels of family-related LS. The participants perceiving that important others understand their illness, expect it to have more consequences for the participants' everyday life, and at the same time not noticing many symptoms, seem to be more satisfied with their family life.

The identity dimension of perceived important others' illness representations was also predictive of friendship and life environment LS domains. In friendship domain identity was the only significant predictor. The participants who perceived that their important others notice less symptoms of illness report on higher levels of satisfaction with their friendships. The same also turned out to be the case in the life environment-related domain. Additionally, lower scores on the identity scale together with lower scores on peer-reported personality dimension openness were associated with higher levels of LS. The participants who perceived their important others to notice less symptoms of illness and were described as less open reported more satisfaction with their living environment.

In self-related LS domain the participants who perceived their important others to understand the illness and expect it to be amenable to personal control were more likely to achieve higher levels of satisfaction.

Finally, in school-related domain none of the predictors was statistically significant (all of the predictors accounted for $17 \%$ of variance). 


\section{Discussion}

The present study explored the role of personality and illness representations in LS of adolescent/emerging adult hypertensive patients. To our knowledge, the present work is unique in its focus on these issues. Our results supported the hypotheses that some of illness representations and personality traits are predictive of LS in adolescent/emerging adult hypertensive patients. However, we found differential predictive validity of specific illness representations dimensions and personality traits in explaining different domains of LS. We also established the predictive power of the predictors examined to be rather smaller than expected from previous studies.

Originally, the MSLSS does not have established empirical cut-off points to classify the scores into optimal/adequate/ risk levels of LS. However, Suldo and Huebner (2004) have analysed the questionnaire scores. They defined a cut-off point at an average score of 4.0 or greater (up to 6.0) to delineate high LS and scores between 1 and 3.9 to indicate low LS. Accordingly, our participants exhibited relatively high levels of general LS and LS across the specific domains.

\section{The role of illness representations in different domains of life satisfaction}

We obtained two measures of illness representations. The first one referred to the respondents' own illness representations (i.e. "How do I see my illness?"), and the second one focused on perceived important others' illness representations (i.e. "How do I think my important other sees my illness?"). We assumed both measures to predict the participants' life satisfaction across different developmentally central domains, namely family, friendships, school, living environment, self and life in general (Huebner et al., 2004). However, our findings suggest that only emotional components of own illness representations have predictive links to LS domains. Specifically, higher levels of concern about illness were predictive of higher levels of familyrelated LS (with concern being the only significant predictor in the model). Further, greater emotional burden along with higher self-reported agreeableness and emotional stability (lower neuroticism) predicted higher levels of satisfaction in the friendship domain. Lastly, lower levels of concern were predictive of higher levels of LS in the life environment domain.

Based on these findings, the participants who are more worried about the course of their illness seem to experience more satisfaction in their family life and in their broader living environment. Similarly, in previous studies concern was linked to better illness management (e.g., adherence, Žugelj et al., 2010). We assume that family members expect certain levels of concern about illness and appropriate behaviour changes in hypertensive adolescent/emerging adult. Furthermore, stronger cohesion in the understanding of illness among family members results in more effective coping with the illness and higher subjective well-being in adolescent patients (Law et al., 2002; Salewski, 2003).
On the other hand, when we examined perceived important others' illness representations only cognitive dimensions were predictive of specific life satisfaction domains. Namely, identity, comprehension, consequences, and treatment control appeared as the most significant predictors. Considering satisfaction with life in general, participants who found their important others to perceive their illness as less symptomatic (low identity) and at the same time to demonstrate better understanding of illness (high comprehension), reported higher levels of overall life satisfaction. Similarly, these representations were important in predicting family-related life satisfaction, with more perceived consequences as the third significant predictor. Experiencing higher levels of satisfaction in one's family life may have thus been a reflection of perceiving important others to notice fewer symptoms, to demonstrate better comprehension of illness and perceiving the illness to potentially affect one's life. Further, fewer perceived symptoms (identity) by important others were also predictive of the participants' higher levels of satisfaction in the friendship domain. Higher satisfaction with living environment was predicted by fewer perceived symptoms by important others and peer-reported openness (personality). Interestingly, illness representations were only predictive of self-related life satisfaction when reported as perceived representations of important others. In this domain higher treatment control and higher levels of comprehension predicted more satisfaction with one's self. The participants who found their important others to expect treatment to be beneficial for illness control and to demonstrate higher levels of comprehension exhibited higher levels of self-related life satisfaction.

In the self-related domain higher treatment control was related to higher levels of life satisfaction (in combination with lower levels of peer-reported openness). Similarly, the perceived higher treatment efficiency to control illness predicted higher levels of well-being in adolescent patients with diabetes (Edgar \& Skinner, 2003). However, in our study perceived important others' illness representations and not own illness representations treatment control dimension predicted higher self-related life satisfaction. This might indicate that our participants still share the responsibility for treatment with their important others and thus rely on their judgment. Moreover, the participants themselves do not report on perceiving a high illness impact on their lives, but having a social network that finds treatment important might contribute to their overall attitude towards illness and also life satisfaction. Similarly, low identity score, obtained as perceived others' representation dimension, was consistently shown to predict higher levels of satisfaction, i.e., in general LS, as well as in the family, friendship, and living environment domains. Again, we assume that young patients still rely on their close ones' judgement when facing life challenges. Therefore, when being faced with a chronic illness diagnosis, one checks how this resonates in her/his close relationships. When others do not seem to notice that there is much evidence of illness, one incorporates this in her/ his own model of illness. 
To sum up, it appears that experiencing some level of concern regarding the illness, possibly in combination with important others' involvement and comprehension of illness, contributes to higher levels of life satisfaction in respective domains in adolescent/emerging adult hypertensive patients.

We must note, however, that obtained predictive values were relatively modest compared to those reported in literature. This might be explained by the difference in indicators of adaptation to illness taken into consideration. Researchers (e.g., Edgar \& Skinner, 2003; Law et al., 2002; Salewski, 2003) have usually investigated the role of patients' illness perceptions in relation to measures of health-related quality of life. We, on the other hand, assessed life satisfaction in domains not necessarily directly connected to illness, but relevant from the developmental point of view for both healthy and chronically ill adolescents and emerging adults (Huebner et al., 2004). In addition, our participants (or their important others) rarely perceived their high blood pressure to affect their everyday lives notably. In general, they did not consider their illness to have any important consequences for their lives. They experienced few symptoms, if any, and mostly appeared emotionally unaffected by their illness. According to the medical definition of essential hypertension (Varda \& Gregorič, 2005), the illness is non-symptomatic, so that a perceived low impact of essential hypertension is expected. However, it is possible that the predictive power of illness representations would be higher if the medical conditions were more demanding and affected the adolescents' and emerging adults' functioning more severely. Further research is needed to evaluate these assumptions.

\section{The role of personality traits in different domains of life satisfaction}

When reported by participants themselves, agreeableness and neuroticism emerged as the most important predictors of some life satisfaction domains. More specifically, agreeableness was the only significant predictor in general and school life satisfaction domain. In both cases, participants that are more agreeable reported higher levels of satisfaction. In friendship-related satisfaction domain, agreeableness, emotional stability (low neuroticism), and (higher) emotional burden (own illness perceptions) were statistically significant predictors. On the other hand, among peer-reported personality traits only openness significantly predicted one aspect of life satisfaction, i.e., living environment satisfaction.

As mentioned, agreeableness was the most consistent predictor among the five personality traits. Costa and McCrae (1980) proposed that in the context of the Big Five personality model, extraversion and neuroticism affect subjective wellbeing directly (life satisfaction being one of the components), while agreeableness, conscientiousness, and openness are instrumental to subjective well-being. Higher levels of the latter three traits affect subjective well-being indirectly through more favourable social relationships, better academic achievement, and similar positive outcomes. Individuals high as opposed to those low on agreeableness are referred to as friendly, cooperative, respectful, empathetic, and ready to adjust to other people's needs (Caspi, Roberts, \& Shiner, 2005;
Halverson et al., 2003). These relatively enduring behavioural tendencies generally promote positive social relationships, and may thus contribute to warm, considerate, harmonious, and satisfying relationships with peers and authorities in school (e.g., Zupančič \& Kavčič, 2009), which could contribute to perceptions of higher levels of friendship- and school-related life satisfaction in more agreeable adolescents and emerging adults. In other words, the effect of agreeableness in these domains could be due to the presumed instrumental role of this trait (Costa \& McCrae, 1980).

Furthermore, self-reported agreeableness, neuroticism, and illness representations dimension emotional burden significantly predicted friendship-related life satisfaction. It suggests that the participants who describe themselves as more agreeable, more emotionally stable, and experience a greater emotional toll due to their illness tend to be more satisfied with their friendships. These adolescents are generally not susceptible to distress and negative emotionality (characteristic of emotional stability), even though they report more negative emotions in relation to their illness. When combined with higher levels of agreeableness, higher levels of friendships satisfaction are expected.

Even though others usually tend to report similar personality traits as are obtained with self-report, we found only self-reported and not peer-reported traits significant in predicting life satisfaction in most of the domains. Perhaps we can assume this is due to relative subjectivity of the life satisfaction concept. Thus it is more related to own perception of personality.

\section{Study limitations and strengths}

Our results should be interpreted with caution due to some limitations. Limitations of this study include a small number of participants relative to the number of measures employed. Therefore, replication in a larger sample is suggested. Future research could further explore changes in illness representations over time as participants grow older and illness develops. Additionally, interventional study design would enable assessing causal relationships. In regard to measures employed, a direct insight into the illness representations of the adolescents' and emerging adults' important others would be welcome. Direct assessments of important others' illness representations would allow us to parallel the findings with similar studies of other paediatric patients (which mainly use such direct assessments), and different views on illness in the participants' social network. Additionally, when the participants responded about their perceptions of important others' illness representations, they were not required to specify who they had in mind, which could affect the reliability and validity of the respective results. Finally, though strongly recommended in related literature (e.g., Leventhal, Weinman, Leventhal, \& Philips, 2008), our study limitations did not allow us to control for the illness outcomes (e.g., blood pressure levels, severity of illness). Therefore, we strongly suggest that future studies employ a longitudinal and multiple-informant design, and control for the illness outcomes. 


\section{Study implications}

The results of our study offer some (although limited) support for the relevance of illness representations in several domains of adolescents' and emerging adults' life satisfaction. Both emotional and cognitive components of those representations seem to play a role, however, it seems that one's own emotional components of illness representations play a more important role compared to the cognitive dimensions of illness representations. Cognitive dimensions become important in predicting life satisfaction when perceived in important others. However, due to study limitations these links need to be explored further.

Patients form their illness representations on different sources, with doctors and their alliances being one of the most influential (Hagger \& Orbell, 2003; Leventhal et al., 2004). Other sources are young patients' important others, their social and cultural milieus, and their own experiences. The information, attitudes, and beliefs about illness coming from these "non-medical" sources can be more or less consistent with the medical definition of the illness in question. Thus, doctors and other medical staff are encouraged to check adolescents'/emerging adults' own illness representations regularly in order to detect any possible misconceptions, and to obtain a constructive mutual understanding of the illness. Such an understanding is fundamental to employing more favourable attitudes, and thus increases the likelihood of better adjustment to illness. Furthermore, our findings might indicate the importance of refining the examination of illness representations. We propose that further investigations should also tap into participants' perceptions of their closeones' operationalisations and understanding of their illness, as they might reflect perceived social representations and perhaps even perceived social (family) support. The patients' perceived social support has in particular been shown to enhance treatment adherence, improve treatment outcomes, and predict better adaptation to illness in general (La Greca \& Bearman, 2003).

Additional consideration of patients' personality would allow doctors to identify the patients at greater risk for poor adaptation to illness. Our results, for example, suggest that adolescents/emerging adults scoring higher on agreeableness tend to experience higher levels of life satisfaction in different domains. Differential, individually-based behavioural interventions accounting for relevant moderating variables (e.g., personality traits) are thus proposed to contribute to more favourable treatment outcomes (optimal levels of life satisfaction being one of them) than use of common methods for all patients (Kreamer, Willson, Fairbourn, \& Agras, 2002).

On the broader scale, we hope our study to inform research on other chronic illnesses among youth. There are abundant reports of adult perceptions of different illnesses, yet reports about perceptions of adolescent/emerging adults with chronic illnesses are relatively scarce. Understanding better how young patients with a chronic illness perceive their condition may be beneficial in enhancing education regarding longterm outcomes and achieving desired treatment outcomes.

\section{References}

Bardage, C., \& Isacson, D. G. (2001). Hypertension and health-related quality of life: An epidemiological study in Sweden. Journal of Clinical Epidemiology, 54(2), 172-181.

Broadbent, E., Petrie, K. J., Main, J., \& Weinman, J. (2006). The Brief Illness Perception Questionnaire (BIPQ). Journal of Psychosomatic Research, 60, 631-637.

Caspi, A., Roberts, B. W., \& Shiner, R. L. (2005). Personality development: Stability and change. Annual Review of Psychology, 56, 453-484.

Chong, J., Mackey, A. H., Broadbent, E., \& Stott, N. S. (2012). Children's perceptions of their cerebral palsy and their impact on life satisfaction. Disability \& Rehabilitation, 34(24), 2053-2060.

Costa, P. T., Jr., \& McCrae, R. R. (1980). Influence of extraversion and neuroticism on subjective well-being: Happy and unhappy people. Journal of Personality and Social Psychology, 38, 668-678.

De Bolle, M., De Clercq, B., De Fruyt, F., \& Benoit, Y. (2008). Self- and parental perspectives on quality of life in children with cancer. Journal of Psychosocial Oncology, 26(2), 35-47.

DeNeve, K. M., \& Cooper, H. (1998). The happy personality: A meta-analysis of 137 personality traits and subjective well-being. Psychological Bulletin, 124(2), 197-229.

Diener, E., Suh, E., Lucas R., \& Smith, H. (1999). Subjective well-being: Three decades of progress. Psychological Bulletin, 125, 276-302.

Edgar, K. A., \& Skinner, T. C. (2003). Illness representations and coping as predictors of emotional well-being in adolescents with Type 1 diabetes. Journal of Pediatric Psychology, 28(7), 485-493.

Edwards, T. C., Patrick, D. L., \& Topolski, T. D. (2003). Quality of life of adolescents with perceived disabilities. Journal of Pediatric Psychology, 28(4), 233-241.

Finset, A., \& Gerin, W. (2008). How can we promote medication adherence and lifestyle changes in hypertensive patients? Patient Education and Counseling, 72(2), 1-2.

Fogle, L. M., Huebner, E. S., \& Laughlin, J. E. (2002). The relationship between temperament and life satisfaction in early adolescence: Cognitive and behavioral mediation models. Journal of Happiness Studies, 3(4), 373-392.

Gilman, R., Huebner, E. S., \& Laughlin, J. (2000). A first study of the Multidimensional Students' Life Scale with adolescents. Social Indicators Research, 52, 135-160.

Hagger, M. S., \& Orbell, S. (2003). A meta-analytic review of the common sense model of illness representations. Psychology and Health, 18, 141-184.

Halverson, C. F., Havill, V. L., Deal, J., Baker, S. R., Victor, J. B., Pavlopoulos, ... Wen L. (2003). Personality structure as derived from parental ratings of free descriptions of children: The Inventory of Child Individual Differences. Journal of Personality, 71, 995-1026.

Helgeson, V. S., \& Novak, S. A. (2007). Illness centrality and well-being among male and female early adolescents with diabetes. Journal of Pediatric Psychology, 32(3), 260-272. 
Hildingh, C., \& Baigi, A. (2010). The association among hypertension and reduced psychological well-being, anxiety and sleep disturbances: A population study. Scandinavian Journal of Caring Sciences, 24, 366-371.

Huebner, E. S. (1994). Preliminary development and validation of a Multidimensional Life Satisfaction Scale for Children. Psychological Assessment, 6, 149-158.

Huebner, E. S., Valois, R. F., Suldo, S. M., Smith, L. C., McKnight, C. G., ... Zullig H. J. (2004). Perceived quality of life: A neglected component of adolescent health assessment and intervention. Journal of Adolescent Health, 34, 270-278.

Knyazev, G. G., Zupančič, M., \& Slobodskaya, H. R. (2008). Child personality in Slovenia and Russia: Structure and mean level of traits in parent and self-ratings. Journal of Cross-Cultural Psychology, 39, 317-334.

Kreamer, H. C., Willson, T., Fairbourn, C. G., \& Agras, S. (2002). Mediators and moderators of treatment effects in randomized clinical trials. Archives of General Psychiatry, 59(10), 877-883.

La Greca, A. M., \& Bearman, K. J. (2003). Adherence to pediatric treatment regimens. In M. C. Roberts (Ed.), Handbook of pediatric psyhology (str. 119-140). New York, NY, USA: Guilford Press.

Law, G. U., Kelly, T. P., Huey, D., \& Summmerbell, C. (2002). Self-managemant and well-being in adolescents with diabetes mellitus: Do illness representations play a regulatory role? Journal of Adolescent Health, 31, 381-385.

Leventhal, H., Halm, E., Horowitz, C., Leventhal, E. A., \& Ozakinci, G. (2004). Living with chronic illness: A contextual, self-regulation approach. In S. Sutton, A. Baum, \& M. Johnston (Eds.), The Sage handbook of health psychology (pp. 197-240). London, UK: Sage.

Leventhal, H., Weinman, J., Leventhal, E. A., \& Philips, L. A. (2008). Health psychology: The search for pathways between behavior and health. Annual Review of Psychology, 59, 477-505.

Marcionetti, J., \& Rossier, J. (2016). Global life satisfaction in adolescence: The role of personality traits, self-esteem, and self-efficacy. Journal of Individual Differences, $37(3), 135-144$.

Petrie, K. J., \& Weinman, J. (2006). Why illness representations matter? Clinical Medicine, 6(6), 536-539. doi: 10.7861/clinmedicine.6-6-536

Petrie, K. J., \& Weinman, J. (2012). Patients' perceptions of their illness: The dynamo of volition in health care. Current Directions in Psychological Science, 21, 60-65.

Proctor, C. L., Linley, P. A., \& Maltby, J. (2009). Youth life satisfaction: A review of literature. Journal of Happiness Studies, 10, 583-630.
Salewski, C. (2003). Illness representations in families with a chronically ill adolescent: Differences between family members and impact on patients' outcome variables. Journal of Health Psychology, 8(5), 587-598.

Sawyer, M. G., Reynolds, K. E., Couper, J. J., French, D. J., Kennedy, D., Martin, J., ... Baghurst, P. A. (2005). A two-year prospective study of the healthrelated quality of life of children with chronic illness: The parents' perspective. Quality of Life Research: An International Journal of Quality of Life Aspects of Treatment, Care \& Rehabilitation, 14(2), 395-405.

Steel, P., Schmidt, J., \& Shultz, J. (2008). Refining the relationship between personality and subjective wellbeing. Psychological Bulletin, 134, 138-161.

Suldo, S., \& Huebner, E. (2004). The role of life satisfaction in the relationship between authoritative parenting dimensions and adolescent problem behavior. Social Indicators Research, 66, 165-195.

Varda, N. M., \& Gregorič, A. (2005). A diagnostic approach for the child with hypertension. Pediatric Nephrology, 20, 499-506.

Vitterso, J. (2001). Personality traits and subjective wellbeing: Emotional stability, not extraversion, is probably the important predictor. Personality and Individual Differences, 31(6), 903-914.

Weber, M., \& Huebner. S. E. (2015). Early adolescents' personality and life satisfaction: A closer look at global vs. domain-specific satisfaction. Personality and Individual Differences, 83, 31-36.

Zupančič, M., \& Kavčič, T. (2009). Vprašalnik o medosebnih razlikah za otroke in mladostnike (VMR-OM): Priročnik [The Inventory of Child and Adolescent Individual Differences: Manual]. Ljubljana, SI: Center za psihodiagnostična sredstva.

Žugelj, U. (2010). Dejavniki psihosocialne prilagoditve na kronično bolezen pri mladostnikih: Primer esencialne hipertenzije (neobjavljeno doktorsko delo) [Factors of psychosocial adaptation to chronic illness in adolescents: a case of essential hypertension (unpublished doctoral dissertation)]. Faculty of Arts, University of Ljubljana, Slovenia.

Žugelj, U., Zupančič, M., Komidar, L., Kenda, R., MarčunVarda, N., \& Gregorič, A. (2010). Self-reported adherence behavior in adolescent hypertensive patients: The role of illness representations and personality. Journal of Pediatric Psychology, 35(9), 1049-1060. 